\title{
Field Response of New Peanut Cultivar UF 91108 to Tomato Spotted Wilt Virus
}

\author{
A. K. Culbreath, Associate Professor, Department of Plant Pathology, and J. W. Todd, Professor, Entomology De- \\ partment, The University of Georgia Coastal Plain Experiment Station, Tifton 31793-0748; D. W. Gorbet, Profes- \\ sor, University of Florida, North Florida Research and Education Center, Marianna 32446; F. M. Shokes, Professor, \\ University of Florida, North Florida Research Center, Quincy 32351; and H. R. Pappu, Assistant Professor, The \\ University of Georgia Coastal Plain Experiment Station, Tifton 31793-0748
}

\begin{abstract}
Culbreath, A. K., Todd, J. W., Gorbet, D. W., Shokes, F. M., and Pappu, H. R. 1997. Field response of new peanut cultivar UF 91108 to tomato spotted wilt virus. Plant Dis. 81:1410-1415.

Epidemics of spotted wilt, caused by tomato spotted wilt tospovirus (TSWV), were monitored in field plots of the new runner-type peanut (Arachis hypogaea) cv. UF 91108, in advanced breeding line F 84 × 9B-4-2-1-1-2-b2-B, in runner-type peanut cvs. Southern Runner and Florunner, and in Virginia-type cv. NC-V11 at two locations in 1994 and 1995. Epidemics of spotted wilt were suppressed in UF 91108 compared to the standard runner-type cv. Florunner. Final disease incidence, standardized area under the disease progress curve values, and final disease intensity ratings were lower in UF 91108 than in Florunner and were similar to those in the moderately resistant cv. Southern Runner. Results indicate that new cv. UF 91108 represents a new potential tool for management of spotted wilt in peanut production areas of the southeastern United States. UF 91108 is the first peanut cultivar in which an oil composition of approximately $65 \%$ oleic acid is combined with a moderate level of field resistance to TSWV. Epidemics of spotted wilt also were suppressed in breeding line F $84 \times 9 \mathrm{~B}-4-2-1-1-2-b 2-\mathrm{B}$. Across the four tests, the effects of NC-V11 on epidemic development, final incidence, and spotted wilt intensity ratings were not consistent relative to the other genotypes. Use of final disease intensity ratings provided separation of the genotypes similar to use of final incidence of spotted wilt. Assessment values by these two methods were highly correlated. In three of four experiments, final disease intensity ratings were more closely correlated with pod yield than was final incidence. The new intensity rating method described in this paper requires much less time and effort than determining disease incidence and may be a practical alternative to individual plant assessment for characterization of genotype responses to TSWV.
\end{abstract}

Additional keywords: disease resistance, epidemiology, Frankliniella fusca, F. occidentalis, groundnut, multiple pathogen resistance, thrips

Since 1985, epidemics of spotted wilt, caused by tomato spotted wilt tospovirus (TSWV), have become progressively more prevalent and more severe in peanut (Arachis hypogaea $\mathrm{L}$.) production areas in the southeastern United States $(6,11,13)$. Spotted wilt has become a major limiting factor for many peanut producers. Control options for spotted wilt are limited. Manipulation of planting date $(12,13)$ and establishing high within-row plant densities (9) may provide some suppression of spotted wilt epidemics but do not provide adequate levels of control. Control of thrips, the vectors of TSWV, has shown little promise for control of spotted wilt $(18,19)$.

Corresponding author: A. K. Culbreath

E-mail: Spotwilt@tifton.cpes.peachnet.edu

This research was supported, in part, by Georgia and Florida peanut growers through grants from the Georgia Agricultural Commodity Commission for Peanuts and check-off funds from the Florida Peanut Producers' Association.

Accepted for publication 18 August 1997.

Publication no. D-1997-0930-02R

(C) 1997 The American Phytopathological Society
Availability of cultivars expressing moderate levels of resistance to TSWV has potential for management of spotted wilt, as indicated by suppression of spotted wilt epidemics using runner-type cvs. Southern Runner (2,4,6,7), Georgia Browne (4), and Georgia Green (7). New cultivars are needed that combine resistance to TSWV with resistance to important fungal pathogens, and characterization of the field response to TSWV, as well as prominent fungal pathogens, has become an essential part of the evaluations for any peanut breeding line with potential for release as a cultivar to be grown in the southeastern United States. Previous reports of genotype effects on spotted wilt epidemics have been based on incidence of the plant population with symptoms of spotted wilt. In those studies, incidence was determined by examining individual plants for symptoms and marking individual symptomatic plants with colorcoded surveyor's flags. Because of the intertwining of branches of adjacent plants, assessment of spotted wilt incidence in runner-type peanut genotypes by this method is extremely time-consuming and laborintensive, even when plant stands are thinned to 1 plant per $20 \mathrm{~cm}$ as described by Culbreath et al. (7). Determination of incidence by this method is even more difficult when more dense populations of plants are used.

Therefore, this method often is impractical for assessments in production fields or research plots when standard plant populations are used.

A disease assessment method is needed that allows rapid determination of the intensity of spotted wilt for genotype or treatment evaluations. A method developed by Rodriguez-Kabana et al. (14) for enumerating foci of southern stem rot (Sclerotium rolfsii Sacc.) in peanut is commonly used in peanut disease research for evaluation of stem rot in peanut rows before or immediately after digging and inversion. By this method, foci are designated as $0.31 \mathrm{~m}$ or less of linear row with plants showing symptoms of stem rot or signs of $S$. rolfsii. In this study, we used a modified version of the method described by Rodriguez-Kabana et al. (14) for enumerating foci of peanut severely affected by spotted wilt.

Incidence, as determined in previous works, can be used to characterize genotype effects on spotted wilt epidemics but often does not correlate well with pod yields. One objective of this study was to adapt this method for determining the foci of peanut plants severely affected by spotted wilt and to examine the correlation between the number of spotted wilt foci and percent incidence of spotted wilt determined by previous examination methods for characterizing field response of runner-type peanut genotypes to spotted wilt.

Recently, the advanced breeding line UF 91108 from the University of Florida peanut breeding programs was approved for release as a runner-type cultivar. Based on pod yield, grades, pod and seed kernel qualities, improved oil chemistry (higher percentage of oleic acid) compared to most of the other available cultivars and moderate levels of resistance to Cercosporidium personatum (Berk. \& Curt) Deighton (10) and $S$. rolfsii (16), UF 91108 is a unique cultivar that has potential as an important resource for peanut production. UF 91108 also has been identified in preliminary field screening experiments as having lower incidences of spotted wilt than those of Florunner. The combination of an oil composition of approximately $65 \%$ oleic acid in UF 91108 (D. W. Gorbet, unpublished data) with any resistance to TSWV and 
other acceptable agronomic properties would be a significant landmark in peanut breeding, especially because the "high oleic" (greater than $80 \%$ oleic acid) acid cv. Sunoleic 95 and many of the breeding lines with the high oleic acid trait are extremely susceptible to TSWV.

The objectives of this study were to characterize the effects of UF 91108 on epidemics of spotted wilt, using both disease incidence based on individual plants and percentage of the row length severely affected by spotted wilt to compare disease progress, disease severity, and pod yields of this new cultivar with the runner-type cvs. Florunner and Southern Runner and to evaluate the advanced breeding line F $84 \times 9 \mathrm{~B}-4-2-$ 1-1-2-b2-B and NC-V11, a Virginia-type cultivar, for field resistance to TSWV. As part of the spotted wilt characterization, the effects of these genotypes on numbers of tobacco thrips, Frankliniella fusca Hinds, and western flower thrips, $F$. occidentalis Pergande, two vectors of TSWV present in Georgia, and larvae of Frankliniella spp. also were examined.

\section{MATERIALS AND METHODS}

Field plot designs. Tests were conducted at The University of Georgia Attapulgus Research Farm, Attapulgus (Decatur County), and at the North Florida Research and Education Center, Marianna (Jackson County), in 1994 and 1995. Soil type was Dothan loamy sand ( $\mathrm{pH}$ 5.8) for fields at Attapulgus and Orangeburg loamy sand $(\mathrm{pH}$ 6.0) for fields at Marianna. Randomized complete block designs with six replications were used in both years and both locations. Naturally occurring thrips populations and resultant infections of TSWV were utilized in all tests.

Treatments in all tests consisted of advanced peanut breeding lines F $84 \times 9 \mathrm{~B}-4-$ 2-1-1-2-b2-B (henceforth referred to as $\mathrm{F}$ $84 \times 9 B)$ and UF 91108, runner-type peanut cvs. Southern Runner and Florunner, and Virginia-type cv. NC-V11. Planting dates were 19 April 1994 and 4 April 1995 at Attapulgus, and 22 April 1994 and 6 April 1995 at Marianna. Florunner and Southern Runner entries in the 1994 test at Marianna also were common standards used to evaluate Georgia Green reported in a previous work (7). Plant populations in all plots were thinned to 1 plant per $20 \mathrm{~cm}$ of row. Plant populations were lower than recommended for commercial peanut production to promote higher incidence of spotted wilt (9) and facilitate observation of spotted wilt symptoms in individual plants. Plots were two rows, $1.8 \mathrm{~m}$ wide $\times 6.1 \mathrm{~m}$ long. All plots at Attapulgus were bordered on both sides by susceptible cv. Tamrun 88 to increase overall incidence of spotted wilt in all entries (1). Each plot at Marianna was bordered on one side by Tamrun 88 . Plants in each plot were counted 22 days after planting (DAP) in 1994, 20 DAP in 1995 at Attapulgus, and 19 DAP in 1994 and 48
DAP in 1995 at Marianna to determine the initial plant population.

All tests were maintained as recommended for commercial peanut production. Chlorothalonil (Bravo 720 or Evade 500) or tebuconazole (Folicur 3.6 F) was applied as a foliar spray at 7- to 14-day intervals for foliar and soilborne fungal disease control. Plants were dug and inverted at approximate optimum maturity for each cultivar based on the hull-scrape maturity index (20) and visual maturity estimates. Entire plots were harvested for yield estimates. Inverted plants were dried in the wind-row for 3 to 7 days. Pods were harvested mechanically, and pod yields were determined for each plot.

Thrips sampling. Thrips populations among the entries were compared, using multiple sample dates and sample types. In 1994, numbers of thrips per 10 whole seedlings, 10 quadrifoliolate terminal leaves, and 10 open flowers were compared among the entries in both experiments. Ten whole plants were collected from each plot 21 DAP at Attapulgus and 19 DAP at Marianna. Subsequently, 10 partially unfolded quadrifoliolate terminal leaves were collected from each plot 29, 36, and 42 DAP at Attapulgus and 26, 33, and 39 DAP at Marianna. Ten flowers were collected from each plot 42 , 49, and 56 DAP at Attapulgus and 46, 53, and 60 DAP at Marianna. In 1995, only leaf samples were used for genotype comparisons. Ten terminal quadrifoliolate leaves were collected from each plot on 27, 34, and 42 DAP at Attapulgus and 27, 36, and 43 DAP at Marianna.

Whole plants, quadrifoliolate leaf terminals, and flower samples were collected and processed as described by Chamberlin et al. (3). Immediately after collection, samples were placed in vials of $70 \%$ ethanol and refrigerated until thrips could be removed and counted in the lab. Thrips were sorted and counted according to species, sex, and life stage. Due to extreme difficulty in differentiating larvae, thrips larvae in the genus Frankliniella were counted without regard for species. Previous studies indicate that these larvae are almost exclusively F. fusca (19).

Disease evaluation. Plants in each plot were evaluated for symptoms of spotted wilt $35,43,50,57,63,70,78,84,92$, and 112 DAP in 1994 and 41, 55, 69, 84, 98, 113, and 125 DAP in 1995 at Attapulgus. Plants were evaluated for symptoms of spotted wilt 35, 51, 65, 79, 94, and 109 DAP in 1994 and 48, 61, 75, 89, 103, 117, and 131 DAP in 1995 at Marianna. On each evaluation date, all plants of each plot were examined individually for symptoms of spotted wilt. Symptoms included concentric ringspots, "oak-leaf" patterns of chlorosis, bronzing of leaves, stunting, and distortion, and necrosis of leaves in the terminal bud. Plants with symptoms on one leaflet or more were designated as symptomatic. To aid in subsequent evaluations, the loca- tion of each symptomatic plant was marked with a color-coded surveyor flag. Symptoms of spotted wilt may appear on runners of one plant that have intertwined with runners of another plant. Therefore, flags were placed immediately adjacent to the main stems of plants on which symptoms were found, regardless of where symptoms were found on the plant. All plants exhibiting symptoms on a given date were marked with flags of the same color; a different color was used for each subsequent evaluation date.

In all tests, disease progress curves were constructed for each entry, using disease incidence, which is the percentage ( 0 to 100) of plants in each plot with symptoms of spotted wilt. Asymptomatic infections of TSWV in peanut have been reported (5), but all discussion of incidence in this study refers only to symptomatic plants. Area under the disease progress curve (AUDPC) was calculated for each plot according to the method of Shaner and Finney (15), using time in days after planting and apparent disease incidence. Standardized areas under the disease progress curves (SAUDPC) were calculated for the four experiments by dividing the AUDPC value for each plot by the total time (days) during which the epidemic was monitored (8).

Plots also were evaluated by a disease intensity rating that represents a combination of incidence and severity. Immediately prior to digging, the number of foci of plants severely affected by spotted wilt were counted for each plot. A locus represented $0.31 \mathrm{~m}$ or less of linear row with plants severely stunted, killed, or showing severe chlorosis from spotted wilt. Distinct reductions in height or width of the peanut row were required before portions of row would be considered severely affected with regard to stunting. There was a maximum number of 20 foci possible in any row. This method was adapted from a similar method for assessing incidence of southern stem rot on inverted peanut plants, reported by Rodriguez-Kabana et al. (14). Because of the intertwining growth habit of runner-type peanut plants, individual plants of many genotypes are not easily distinguishable within 40 to 50 days after emergence, and the row becomes a continuous hedge of overlapping runners. Therefore, use of the $0.31-\mathrm{m}$ foci, such as are used for stem rot evaluations, is suitable for enumerating the spotted wilt foci, even when individual plants initially are $0.2 \mathrm{~m}$ or farther apart. The number of foci of plants severely affected by spotted wilt was converted to a percentage of total row length severely affected. In contrast to evaluations for incidence based on mere presence of symptoms on individual plants, portions of row with plants showing foliar symptoms on a limited portion of the plant were not counted in this evaluation. This evaluation reflected only those portions of rows with plants severely affected by spotted wilt. All flags indicat- 
ing symptomatic plants were removed prior to this evaluation. The percentage of row length severely affected by spotted wilt was used for comparison of the genotypes and for examination of correlations with yield, final incidence, and SAUDPC. Because of an earlier maturity and digging date for NC-V11, this cultivar was not rated for spotted wilt intensity prior to digging at Marianna.

Statistical analysis. All data were subjected to analysis of variance. Data from each location was analyzed independently across years. Fisher's protected least significant difference (LSD) values were calculated for comparison of genotypes (17). Differences referred to in the text are significant at $P \leq 0.05$ unless otherwise indicated. Pearson's correlation coefficients were calculated to examine the correlations among final incidence of spotted wilt, SAUDPC, final spotted wilt intensity ratings, and pod yield across genotypes within each test.

\section{RESULTS}

Year effects were significant for final incidence of spotted wilt, SAUDPC values, final disease intensity ratings, and pod yield in both locations. Differences in develop- ment of epidemics of spotted wilt among years and locations are illustrated by disease progress curves in Figure 1. At Attapulgus, there were no significant year by genotype interaction effects $(P \leq 0.05)$ on final incidence of spotted wilt, SAUDPC values, or final disease intensity ratings. Therefore, data from the 2 years were pooled prior to analysis, and pooled means were used for genotype comparisons (Table 1). Across 2 years at the Attapulgus location, final incidence of spotted wilt and SAUDPC values were higher in Florunner than in all other entries, except NC-V11. Final incidence and SAUDPC values did not differ significantly between Florunner and NCV11. Similar results were obtained with final disease intensity ratings. One exception was that final disease intensity ratings were higher in Florunner than in NC-V11 as well as the other genotypes. Final incidence of spotted wilt, SAUDPC values, and final intensity ratings did not differ among UF 91108, Southern Runner, and F $84 \times 9 B$.

At the Marianna location, there were no significant year by genotype effects on final incidence of spotted wilt or yield. Year by genotype interactions were significant for SAUDPC and final disease intensity ratings (Table 1). Final disease incidence and disease progress curves for Florunner and Southern Runner entries in the 1995 test at Marianna (Table 1 and Fig. 1) have been reported in a previous paper (7) as common standards used to evaluate Georgia Green. Across both years, final incidence in UF 91108, F $84 \times 9 B$, and Southern Runner was lower than in Florunner. Final incidence in NC-V11 was intermediate between Southern Runner and Florunner. Incidence of spotted wilt in F $84 \times 9 \mathrm{~B}$ was lower than that in Southern Runner.

In 1994, SAUDPC values were higher in Florunner than in all other genotypes. SAUDPC values among UF 91108, F $84 \times$ 9B, Southern Runner, and NC-V11 were similar. SAUDPC values were lower for UF 91108 and F $84 \times 9$ B than for Florunner or NC-V11 in 1995. Final spotted wilt disease intensity ratings were higher in Florunner than in UF 91108, Southern Runner, and F $84 \times 9$ B in 1994 and 1995. Intensity ratings were similar for UF 91108 , Southern Runner, and F 84 × 9B, in 1994, whereas intensity ratings in both UF 91108 and F $84 \times 9 \mathrm{~B}$ were lower than those in Southern Runner in 1995.

Genotype effects on yield were not consistent across the 2 years at Attapulgus (Table $1)$. Because of the significant year by ge-
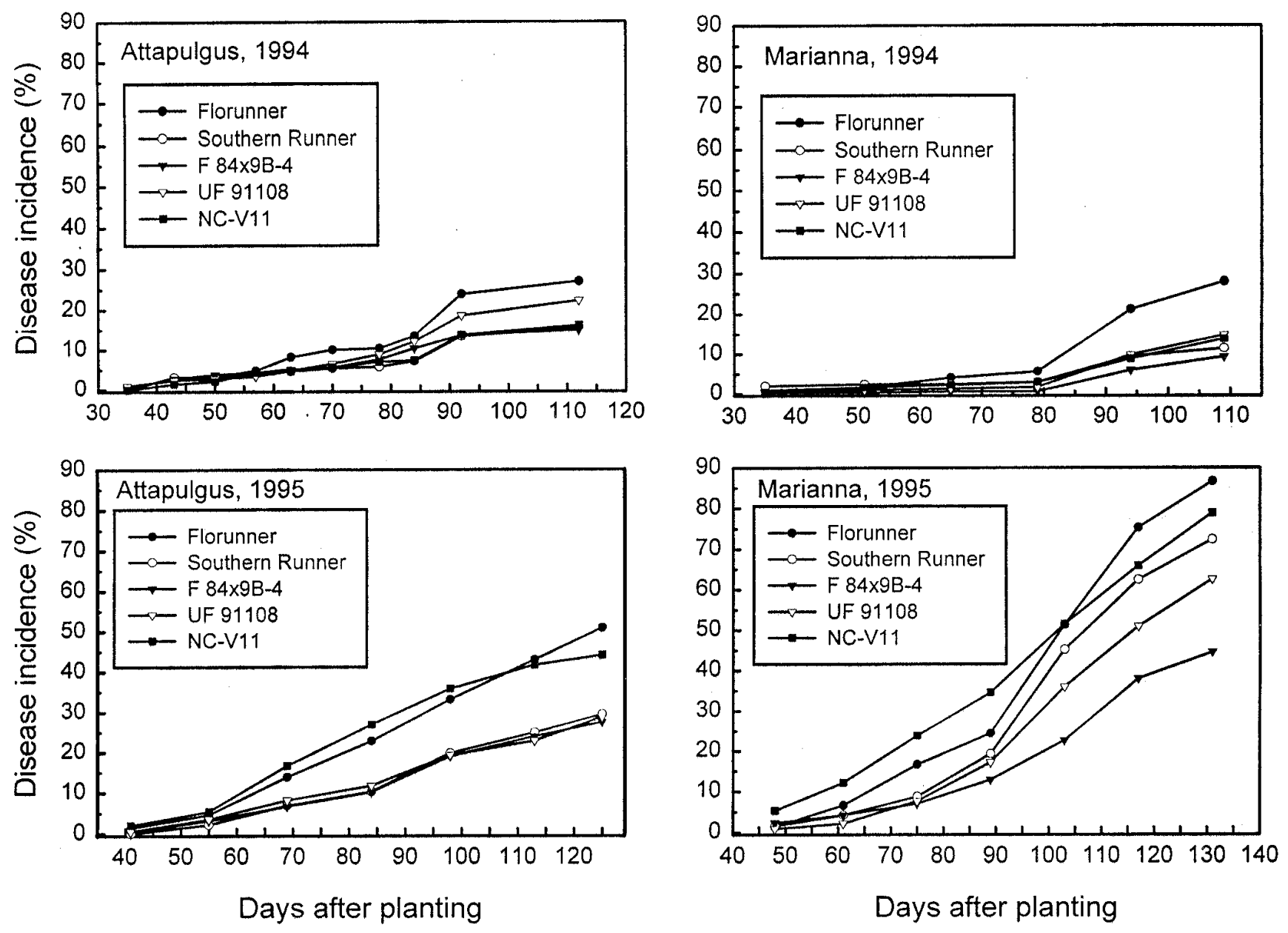

Fig. 1. Effect of peanut genotype on disease progress of spotted wilt caused by tomato spotted wilt tospovirus in Attapulgus, Georgia, and Marianna, Florida, in 1994 and 1995. Disease progress in standard cvs. Florunner and Southern Runner from Marianna in 1994 was previously reported (7). 
notype interaction $(P \leq 0.05)$, yield data were analyzed independently by year. Analysis of variance indicated no significant genotype effects $(P>0.05)$ on yield at Attapulgus in 1994 (Table 1). In 1995, pod yields were similar in UF 91108, Southern Runner, and F $84 \times 9 \mathrm{~B}$, and yields in all three of these genotypes were higher than yields in Florunner or NC-V11.

Across both years at Marianna, pod yield of F $84 \times 9 B$ was higher than that of any other genotype (Table 1). Yields of UF 91108 and Southern Runner were higher than those of Florunner and NC-V11.

Within each test, final incidence of spotted wilt, SAUDPC, and final intensity ratings were highly correlated $(P \leq 0.01)$ across genotypes (Table 2). None of these three variables was correlated $(P>0.23)$ with yield at Attapulgus in 1994. Final spotted wilt intensity ratings were negatively correlated $(P \leq 0.01)$ with pod yield in all other experiments. In three of the four tests, final disease intensity ratings were more closely correlated with yield than was either final disease incidence or SAUDPC.

The results from counts of adult thrips and larvae did not give any indication of consistent differences among the entries. In light of similar findings in previous studies with Southern Runner, Florunner, and other genotypes $(4,6,7)$, data on thrips populations are not shown. The number of samples taken for thrips estimates differed for the 2 years. Therefore, results from 1994 and 1995 were analyzed independently. Few differences in numbers of adults of $F$. fusca or larvae of Frankliniella spp. occurred in either year. No genotype had populations of adults or larvae that were significantly lower than those of Florunner.

Adults of $F$. occidentalis were found in all tests. However, numbers were consistently low (fewer than 4 adults per 10 plants, leaves, or flowers) on all genotypes.

\section{DISCUSSION}

Our results indicate that UF 91108 is a new cultivar with potential for use in management of spotted wilt in peanut-production areas of the southeastern United States.

Table 1. Effect of peanut genotype on final incidence of spotted wilt, standardized areas under the disease progress curve (SAUDPC) values, final spotted wilt intensity ratings, and pod yields in experiments in Attapulgus, Georgia, and Marianna, Florida, in 1994 and 1995

\begin{tabular}{|c|c|c|c|c|c|c|c|c|c|c|c|c|}
\hline \multirow[b]{2}{*}{ Genotype } & \multicolumn{3}{|c|}{ Final disease incidence $^{a}$} & \multicolumn{3}{|c|}{ SAUDPC $^{\mathbf{b}}$} & \multicolumn{3}{|c|}{ Final disease intensity rating ${ }^{c}$} & \multicolumn{3}{|c|}{ Yield (kg/ha) } \\
\hline & 1994 & 1995 & Avg. & 1994 & 1995 & Avg. & 1994 & 1995 & Avg. & 1994 & 1995 & Avg. \\
\hline \multicolumn{13}{|l|}{ Attapulgus } \\
\hline Florunner & 27.0 & 51.1 & $39.1^{\mathrm{d}}$ & 12.7 & 23.5 & $18.1^{\mathrm{d}}$ & 35.4 & 41.3 & $38.3^{\mathrm{d}}$ & $3,842^{\mathrm{e}}$ & $3,361^{\mathrm{e}}$ & $\ldots$ \\
\hline Southern Runner & 15.5 & 29.5 & 22.5 & 7.5 & 12.8 & 10.2 & 10.4 & 12.5 & 11.5 & 3,381 & 4,262 & $\ldots$ \\
\hline F $84 \times 9 B-4-2-1-1-2-b 2-B$ & 14.9 & 27.6 & 21.3 & 8.1 & 12.6 & 10.3 & 10.4 & 12.9 & 11.7 & 3,347 & 4,309 & $\ldots$ \\
\hline UF 91108 & 22.3 & 28.8 & 25.5 & 10.0 & 13.2 & 11.6 & 13.3 & 12.1 & 12.7 & 3,571 & 4,432 & $\ldots$ \\
\hline NC-V11 & 16.1 & 44.2 & 30.2 & 7.6 & 24.6 & 16.1 & 14.6 & 27.9 & 21.3 & 3,232 & 3,747 & $\ldots$ \\
\hline $\operatorname{LSD}^{\mathrm{f}}(P \leq 0.05)$ & & & 9.4 & & & 5.2 & & & 7.1 & NS & 440 & $\ldots$ \\
\hline \multicolumn{13}{|l|}{ Marianna } \\
\hline Florunner & 28.0 & 86.7 & $57.4^{\mathrm{d}}$ & $9.5^{\mathrm{e}}$ & $43.7^{\mathrm{e}}$ & $\ldots$ & $36.3^{\mathrm{e}}$ & $79.6^{\mathrm{e}}$ & $\ldots$ & 4,454 & 2,431 & $3,442^{\mathrm{d}}$ \\
\hline Southern Runner & 11.4 & 72.4 & 41.9 & 4.8 & 35.4 & $\ldots$ & 11.7 & 46.3 & $\ldots$ & 5,069 & 3,668 & 4,369 \\
\hline F $84 \times 9$ B-4-2-1-1-2-b2-B & 9.3 & 44.6 & 27.0 & 2.5 & 21.6 & $\ldots$ & 6.7 & 20.0 & $\ldots$ & 6,043 & 5,164 & 5,604 \\
\hline UF 91108 & 14.7 & 62.6 & 38.7 & 4.3 & 29.2 & $\ldots$ & 11.7 & 27.5 & $\ldots$ & 5,417 & 4,180 & 4,798 \\
\hline NC-V11 & 13.8 & 78.9 & 46.3 & 4.6 & 45.9 & $\ldots$ & $\ldots$ & $\ldots$ & $\ldots$ & 4,545 & 3,304 & 3,925 \\
\hline $\operatorname{LSD}(P \leq 0.05)$ & & & 12.1 & 3.1 & 14.3 & $\ldots$ & 5.2 & 14.2 & $\ldots$ & & & 415 \\
\hline
\end{tabular}

${ }^{a}$ Percentage of the total plant population with symptoms of spotted wilt.

${ }^{b}$ Area under the disease progress curve (AUDPC) values were calculated from disease incidence, using 10 evaluations at Attapulgus in 1994, 7 evaluations at Attapulgus in 1995, 6 evaluations at Marianna in 1994, and 7 evaluations at Marianna in 1995. For analysis across locations and years, AUDPC values were standardized by dividing AUDPC by the total time (days) of the evaluation period. These times were 77 days at Attapulgus in 1994,84 days at Attapulgus in 1995, 73 days at Marianna in 1994, and 70 days at Marianna in 1995.

${ }^{\mathrm{c}}$ Percentage of the total row length with plants severely affected by spotted wilt.

${ }^{\mathrm{d}}$ There were no significant $(P>0.05)$ year by genotype interaction effects for values in the column. Therefore, average means across years were used for genotype comparisons

e There were significant $(P \leq 0.05)$ year by genotype interaction effects for values in the column. Therefore, comparisons of genotypes were made for each test. NS indicates that there were no significant $(P>0.05)$ genotype effects for values in that column.

${ }^{\mathrm{f}}$ Least significant difference.

Table 2. Pearson's correlation coefficients for correlations among final incidence of spotted wilt, standardized area under the disease progress curves (SAUDPC), final spotted wilt intensity ratings, and pod yield in Attapulgus, Georgia, and Marianna, Florida, in 1994 and 1995

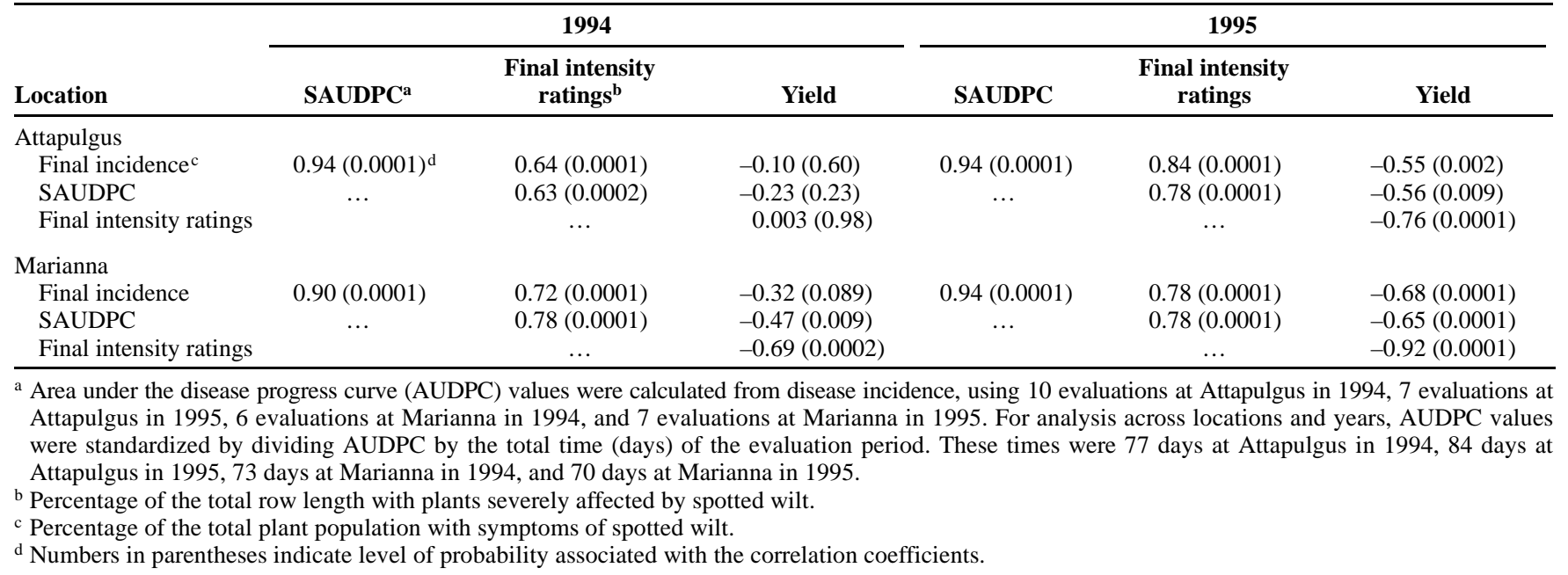


Based on final incidence, disease progress, and late-season spotted wilt intensity ratings, spotted wilt epidemics were suppressed in the new cv. UF 91108 compared to Florunner, a standard runner-type cultivar grown in the southeastern United States. The effects of UF 91108 on spotted wilt epidemics were similar to those of Southern Runner, which previously has been reported to suppress epidemics of spotted wilt $(2,4$, $6,7)$. UF 91108 combines traits of impeding spotted wilt epidemics with an oil composition of approximately $65 \%$ oleic acid (D. W. Gorbet, unpublished data). UF 91108 is the first cultivar in which this level of oleic acid is combined with such a field response to spotted wilt. This is especially noteworthy because cv. Sunoleic 95, with oleic acid levels of greater than $80 \%$, is extremely susceptible to TSWV.

Although the potential for release of $\mathrm{F}$ $84 \times 9 \mathrm{~B}$ as a cultivar remains to be determined, epidemics were suppressed in this genotype as well. Differences in incidence and intensity of spotted wilt of UF 91108 and $\mathrm{F} 84 \times 9 \mathrm{~B}$ relative to Florunner were apparent in tests in which moderate to heavy epidemics developed. There were no consistent differences among Southern Runner, UF 91108, or F 84 × 9B. In 1994, disease progress curves and disease intensity ratings showed minor numerical variation in performance of UF 91108 relative to Florunner and Southern Runner between Attapulgus and Marianna. However, in Marianna in 1995, severity ratings in UF 91108 and $\mathrm{F} 84 \times 9 \mathrm{~B}$ were lower than those of Southern Runner. Differences in the performance of these lines between the two locations have not been explained. The Marianna site in 1995 had the most intense spotted wilt epidemics of any of our experiments. Perhaps these two genotypes are better able to withstand severe epidemics than even Southern Runner. However, with only one test with epidemics that intense, such a conclusion is premature. In three of the four tests, UF 91108 and F $84 \times 9 B$ also had pod yields substantially greater than those of Florunner. Because of possible inherent differences in yield among genotypes, it is not possible to discern in this study what portion of the differences in yield was due to differences in levels of spotted wilt incidence or intensity. These results do indicate, however, that use of either UF 91108 or F $84 \times 9 \mathrm{~B}$ should reduce the risk of losses in yield to spotted wilt compared to Florunner. Epidemic development in NC-V11 was not consistent relative to the other genotypes across years. NC-V11 may be intermediate in its effects on spotted wilt epidemics and may perform similar to Florunner when factors are favorable for severe epidemics, as were observed in 1995.

Epidemic development in UF 91108 and F $84 \times 9 \mathrm{~B}$ indicates that neither of these genotypes is highly resistant to infection. This is similar to findings with cvs. South- ern Runner (6), Georgia Browne (4), Georgia Green (7), and other breeding lines (7). The mechanisms responsible for differences in disease incidence or disease intensity ratings of spotted wilt among the peanut cultivars and breeding lines have not been characterized. Similarly, genetic factor(s) responsible for effects of UF 91108 and $F$ $84 \times 9 \mathrm{~B}$ on epidemics of spotted wilt are not known.

In these tests, efforts were made to maximize potential for development of spotted wilt epidemics. Either UF 91108 or F $84 \times$ 9B should be useful in integrated management regimes that combine cultivar effects with other factors that may help suppress epidemics of spotted wilt. This study corroborates previous reports that differences among cultivars in incidence of spotted wilt could not be attributed to differences in attractiveness to thrips or suitability for thrips reproduction, as indicated by numbers of adult thrips and larvae, respectively $(4,6,7)$.

Although characterization of other traits of F $84 \times 9 \mathrm{~B}$ is still in progress, this breeding line also shows potential for use in management of TSWV. Both UF 91108 and F $84 \times 9$ B may provide moderate levels of resistance to important fungal pathogens of peanut. Resistance to fungal pathogens in a cultivar that can help reduce spotted wilt epidemic development could be very beneficial in peanut production areas where TSWV is endemic and where environmental conditions are conducive for development of fungal diseases. Suppressive effects on multiple diseases by a peanut cultivar or cultivars with improved oil chemistry could become increasingly more important as peanut producers in the United States seek to cut costs of production to become more competitive in the world market.

These results indicate that the use of spotted wilt disease intensity ratings of percent of the row length with plants severely affected by spotted wilt is a practical alternative to disease incidence for comparing genotype effects on spotted wilt epidemics in the field. Values obtained by the two disease assessment methods were highly correlated and provided similar separation of the genotypes being characterized. In addition, disease intensity ratings were more closely correlated with yield than was either final disease incidence or SAUDPC in three of the four tests conducted. None of the three disease variables was correlated with yield in the fourth test. Use of disease intensity ratings for assessment requires much less time and effort than assessments for disease incidence used in previous studies. Furthermore, because runner type peanut plants intertwine so severely, use of an evaluation method that is based on affected length of row should be much more practical than evaluation of individual plants in tests in which higher plant densities are used.

Using the intensity ratings, the degree to which plants are affected also is taken into account. This may partially explain the better correlation of yield with the intensity ratings. Simply counting individual plants that are severely affected might provide a comparable correlation with yield but also would have limitations similar to those of determining disease incidence, considering the intertwining growth habit of peanut plants, even with the sparse plant densities used in this study. Use of this method also may aid in characterization of peanut yield losses as a function of spotted wilt intensity.

\section{ACKNOWLEDGMENTS}

We thank D. Berger, M. Bordelon, W. Branch, C. Bryant, M. Chambliss, D. Dorminy, T. Gavin, P. Goodman, D. Griffin, F. Johnson, R. Krawczyk, T. Matthews, R. Marten, S. McKeown, S. McKeown Jr., R. Meadows, D. Ramer, S. Thompson, S. West, J. White, and D. Willis for their essential efforts.

\section{LITERATURE CITED}

1. Black, M. C., Andrews, T. D., and Smith, O. D. 1993. Interplot interference in field experiments with spotted wilt disease of peanut. Proc. Am. Peanut Res. Educ. Soc. 25:65.

2. Black, M. C., and Smith, D. H. 1987. Spotted wilt and rust reactions in south Texas among selected peanut genotypes. Proc. Am. Peanut Res. Educ. Soc. 19:31.

3. Chamberlin, J. R., Todd, J. W., Beshear, R. J., Culbreath, A. K., and Demski, J. W. 1992 Overwintering hosts and wingform of thrips, Frankliniella spp., in Georgia (Thysanoptera: Thripidae): Implications for management of spotted wilt disease. Environ. Entomol. 21:121 128.

4. Culbreath, A. K., Todd, J. W., Branch, W. D., Brown, S. L., Demski, J. W., and Beasley, J. 1994. Effect of new peanut cultivar Georgia Browne on epidemics of spotted wilt. Plant Dis. 78:1185-1189.

5. Culbreath, A. K., Todd, J. W., and Demski, J. W. 1992. Comparison of hidden and apparent spotted wilt epidemics in peanut. Proc. Am. Peanut Res. Educ. Soc. 24:39.

6. Culbreath, A. K., Todd, J. W., Demski, J. W. and Chamberlin, J. R. 1992. Disease progress of spotted wilt in peanut cultivars Florunner and Southern Runner. Phytopathology 82:766-771.

7. Culbreath, A. K., Todd, J. W., Gorbet, D. W., Branch, W. D., Sprenkel, R. K., Shokes, F. M., and Demski, J. W. 1996. Disease progress of tomato spotted wilt virus in selected peanut cultivars and advanced breeding lines. Plant Dis. 80:70-73.

8. Fry, W. E. 1977. Integrated control of potato late blight-Effects of polygenic resistance and techniques of timing fungicide applications. Phytopathology 68:1650-1655.

9. Gorbet, D. W., and Shokes, F. M. 1994. Plant spacing and tomato spotted wilt virus. Proc. Am. Peanut Res. Educ. Soc. 26:50.

10. Gorbet, D. W., and Shokes, F. M. 1995. Evaluation of groundnut with multiple pest resistance. Abstr. 1013. Eur. J. Plant Pathol. 8th Int. Plant Prot. Congr. The Hague.

11. Hagan, A. K., Weeks, J. R., French, J. C., Gudauskas, R. T., Mullen, J. M., Gazaway, W. S., and Shelby, R. 1990. Tomato spotted wilt virus in peanut in Alabama. Plant Dis. 74:615

12. Hagan, A. K., Weeks, J. R., Gudauskas, R. T. and French, J. C. 1991. Development of control recommendations for TSWV in peanut in Alabama. Proc. Am. Peanut Res. Educ. Soc. 23:52.

13. Mitchell, F. L., Smith, J. W., Jr., Crumley, C. R., and Stewart, J. W. 1991. Management of tomato spotted wilt virus in South Texas peanut fields. Proc. Am. Peanut Res. Educ. Soc. 23:76.

14. Rodriguez-Kabana, R., Backman, P. A., and Williams, J. C. 1975. Determination of yield 
losses to Sclerotium rolfsii in peanut fields. Plant Dis. Rep. 59:855-858.

15. Shaner, G., and Finney, P. E. 1977. The effect of nitrogen fertilizer on expression of slow mildewing resistance in Knox wheat. Phytopathology 67:1051-1056.

16. Shokes, F. M., Gorbet, D. W., and Culbreath, A. K. 1997. Multiple disease resistance of a new mid-oleic peanut cultivar. (Abstr.) Phytopath- ology 87:5115

17. Steel, R. G. D., and Torrie, J. D. 1960. Principles of Statistics. McGraw-Hill Book Co., New York.

18. Todd, J. W., Culbreath, A. K., Chamberlin, J. R., Beshear, R. J., and Mullinix, B. G. 1995. Colonization and population dynamics of thrips in peanuts in the southern United States. Pages 453-460 in: Thrips Biology and Management.
Plenum Press, New York.

19. Todd, J. W., Culbreath, A. K., Rogers, D., and Demski, J. W. 1994. Contraindications of insecticide use relative to vector control for spotted wilt disease in peanut. Proc. Am. Peanut Res. Educ. Soc. 26:42.

20. Williams, E. J., and Drexler, S. 1981. A nondestructive method of determining peanut pod maturity. Peanut Sci. 8:134-141. 